\title{
CORRIGENDUM
}

\section{Temporal changes in bile acid levels and $12 \alpha$-hydroxylation after Roux-en-Y gastric bypass surgery in type 2 diabetes}

R Dutia, M Embrey, S O'Brien, RA Haeusler, KK Agénor, P Homel, J McGinty, RP Vincent, J Alaghband-Zadeh, B Staels, CW le Roux, $\mathrm{J}$ Yu and B Laferrère

International Journal of Obesity (2016) 40, 554; doi:10.1038/ijo.2015.250

Correction to: International Journal of Obesity (2015) 39, 806-813; doi:10.1038/ijo.2015.1; published online 14 April 2015

Since the publication of the above article it has been noted that the author S O'Brien should have been listed as CS O'Brien.

The authors should therefore appear as follows:
R Dutia, M Embrey, CS O'Brien, RA Haeusler, KK Agénor, P Homel, J McGinty, RP Vincent, J Alaghband-Zadeh, B Staels, CW le Roux, $\mathrm{J}$ Yu and $\mathrm{B}$ Laferrère

The corrected article html and online pdf versions have been amended.

The authors wish to apologise for any inconvenience caused. 